\title{
Origins of the Latin American Nationalist Media Discourse
}

\author{
PhD. Cand. Yuliya Goshkina
}

Saint-Petersburg State University,

School of journalism and mass communications

\begin{abstract}
The article deals with the process of formation, development, and manifestation of the distinctive features of a phenomenon called Latin American nationalism and its reflections in the local print media. This theme was chosen because of author's scientific interests related to the study of the nationalist media discourse and specific strategies of political communication presented in contemporary Latin America. In this paper, the author analyzes causes of Latin American nationalism of historical, philosophical and geopolitical positions, describes the process of its gradual transformation and names its standard markers.
\end{abstract}

Keywords: Latin American nationalism, history of political movements, media history

\section{Introduction}

Acute changes observed today in the political processes of Latin American countries are caused by a variety of both endogenous and exogenous factors. Some of them can be called global, typical for any of the existing states, while others are typical only for individual countries or continents.

The policy of no country exists outside its history. Moreover, the policy as "... a sphere of activity that implements the relations of domination and subordination between social classes and strata associated with the conquest, retention, exercise or overthrow and the use of power," often determines history itself.

Discovery of America, its conquest and colonization, prolonged war for independence and its long-awaited acquisition, the experience of building its own state, the economic attractiveness of the region and the persistent unwillingness of the leading world powers to develop equal partnership with Latin America - each of these items contributed to the emergence, consolidation, distribution and centuries-long prosperity of nationalist ideology in this part of the globe.

Active and vibrant social and political life of the countries of Latin America deserves to be discussed seeing many of its features not as an expression of temperament or mentality of local people, but as a consequence of its historical phaseby-phase development.

History of emergence, formation, and development of nationalist ideology can be called the history of its gradual discrediting, erosion of confidence and shamefaced silence of the actual impact. It is not surprising that for most people the word "nationalism" denotes something negative in nature, something akin to a natural disaster or an incurable disease, something so dangerous and violent that even attempts to openly discuss this phenomenon undermine social order and world order, and make to suspect those who wish fiercely to speak on this subject, at best, of a latent gravitation toward mercantilism and protectionism, and at worst - of fascism, expansionism, and separatism.

It should be borne in mind that knowingly negative connotation fixed with the concept under consideration after the World War II and spread, not only in the narrow-minded but also even in academic circles, is not particularly accurate. As well as any other ideology, nationalism has both positive and negative characteristics. It is important to realize that nationalism is diverse and multi-layered, that for understanding and explaining its foundations a more serious study is required and, that ignoring and denying its very existence threatens the society much more than all nationalist young people together. 
English philosopher and social anthropologist Ernest Gellner in his major work "Nations and Nationalism" clearly indicates that the concept of "nationalism" - neutral. For him, this term contains neither any shade of approval nor any shade of disapproval. Nationalism according to Gellner - is primarily an ideology, the principle of social organization, and, therefore, "... it can be good or bad; it can be universal or even unusable, "but it will surely not accept narrow interpretation.

Best part of modern studies criticizing nationalism substantially date back to the fundamental, although not new composition of an American sociologist Charles Tilly, which denies a significant impact of historical and cultural context on the transformation of ideology, does not pay particular importance to regional characteristics of nationalism, however, notes that the Nazi experience of Western Europe in general, and Hitler's Germany, in particular, should not be repeated under any circumstances.

It is significant that for some Latin American scientists Tilly's attitude towards nationalism as to a purely European tragedy is nothing but an extreme degree of Eurocentrism, insisting that developing countries should learn from the mistakes of more experienced and wiser developed countries, and unwilling to recognize the need for integrated approach to the explanation of the reasons for the growing influence of radical nationalist organizations in Latin America.

To study the origins, characteristics, and status of Latin American nationalism open-mindedly one can not rely solely on the European experience. Of course, some elements of Latin American and European nationalism coincide. However, this does not mean that South America with significant delay copied someone else's ideology, not bringing anything of its own. On the contrary, an appearance of nationalism on the continent led to the fact that for a long time it had a consolidating liberating character, was deprived of racial prejudice and mutual claims and was a historically conditioned process of ideologization of only emerging collective community.

Without abandoning the existing relationship with European nationalism, Latin American nationalism, also known as Creole, initially had at the root such goal as the establishment of an independent, but congenial to Spain and Portugal, statecontinent, whose force would consist in its ethnic heterogeneity and empower all its residents with equal rights and responsibilities.

Thus, the emergence of Latin American nationalism was a result of intentional refraction of European nationalist ideology based on local cultural and historical realities. The first impulse to the beginning of this process was the European Enlightenment, through which a slow but steady process of evolution of colonial society began, which resulted in the realization of the identity of people inhabiting the territory of the empire, where the sun never sets.

The idea that talking about the previous appearance of nationalist ideology in Latin America is unqualified, according to Leopold Zea, is reinforced by the fact that earlier such a visible manifestation of responsibility for their future was not observed on the continent. The population was almost indifferent to the current vectors of the development of world politics.

Coming into the territory of Latin America, the ideas of Rousseau and Voltaire, complemented by works of local religious leaders, who by that time had been in a confrontation with the church hierarchs of Spain provoked the first notable surge of popular discontent by the official policy of the metropolis.

The causes and characteristics of this conflict were reflected vividly in the essay of Juan Pablo Vizcardo y Guzman published in 1799 and entitled "Letter to American Spaniards." The abbot Hispanic Jesuit justifies in it any means of a fight of his countrymen against the Spanish Crown, in the event if the ultimate goal of this confrontation is the achievement of independence.

Contemptuous attitude of the Jesuit to the entire Spanish, as alien to the Latin American spirit is manifested, among other things, in the particular political discourse, which he used when describing the downtrodden, impoverished and deprived of their right to speak openly about their origin Creoles. That's why he was seeking new compelling arguments that can not only repel the Spanish aggression but also formulate distinct features, denied by the king of Latin American national community.

Besides, it is just in the book of Vizcardo for the first time in Latin American history such key for building any separatist platform "us and them" concepts as slavery, plunder of the riches, our homeland, liberation, restoration of justice, a large family of friendly people, compatriots are mentioned. In general, the text originally written in French and published in London is characterized by an abundance of figurative comparisons, frequent use of tropes and figures of speech appeals to sense perception. 
A Spanish-language version of this political pamphlet appeared two years later was supplemented by notes and clarifications of General Francisco de Miranda, through which the style of language that had been an extremely hard towards Spain even up to this, became more radical and straightforward. Having found in the work of Vizcardo several separatist Liberation assumptions supporting his conclusions, General Miranda absolutized nationalistic concepts, providing the original text by the phrase of his own, and then using them to create political "Appeal to the People Living on the Columbus American Continent."

The success of the Spanish version of the work of Vizcardo was huge. Creole elite perceived it as a means of Americanization, capable, first, to become the ideological basis of the liberation war of the future, and, secondly, to strengthen their ruling positions in case of victory. The richest Latin American families had a close kinship with the Spanish court, and, therefore, needed to legitimize their power in the countries whose dependence on Spain they also questioned.

In subsequent years, many Latin American newspapers of the period, for example, La Gazeta de Caracas and La Gazeta de Buenos Aires, supported this line. The South American Spaniards suddenly became innocent martyrs of the royal power, shifted all responsibility for atrocities on a distant king and "were purged of original sin, the conquest of America."

The invasion of the Napoleonic troops in Spain, having caused outrage both on the metropolitan territory and on the territory of all its colonies brought Latin American nationalism to a new stage of its development. Despite the fact that the Creole elite due to long-term preparatory measures had already a sufficient degree of independence in this period and not always enthusiastically perceived orders from Madrid, this time it showed surprising unanimity with the people of Spain and refused to recognize the French dominion.

Important role in this was played by its conviction that they not in a less degree, than the Spaniards obliged themselves to preserve their national identity, confirm their affiliation to the great, albeit distant in terms of territory, nation, and the ability to decide their destiny, and not to turn into the usual loose change in the hands of European states. Therefore, the leaders of several Latin American municipalities having supported in absentia the Spanish people fighting for their freedom, found it possible to sign a decree directly related to the situation in Europe, which said that in the case of the final conquest of Spain by Napoleonic France, Latin America, would exercise the right to obey neither new authorities nor the deposed king Fernando VII and would declare the independence of its territories.

Just a few days later, on December 6,1810 , Gaceta de Buenos Aires explicitly stated that "... the links that existed between the monarch and the people of America, have disappeared. Each of the provinces became the mistress to itself. This will continue as long as the public agreements do not determine the relationship between Spain and America directly, and between the king and the American people".

After similar statements had been made in other publications, the Latin American nationalism passed to a new phase of its development. That time it ceased to be a simple means of expressing solidarity with the attacked and gained metropolis and got an individualistic character, became a real ideological support of the struggle for independence - continentalism, which was not based on economic (tax) but political reasons. First time for many years of Spanish rule, the people of South America had begun to realize that the continuous mixing of Indians, Africans, and whites led to the emergence of a community different from the European one deserving to live independently, without focusing on someone's opinion.

One by one on the continent first independent not only of the king but also from each other military juntas appear: in Caracas, Buenos Aires, Bogota, Santiago de Chile, Mexico City. At the same time to strengthen their positions new militaristic leaders had to say that the power they had usurped was granted to them by the sole legitimate ruler of the South American colonies - King Fernando VII. And that the purpose of creating juntas was to maintain order and welfare in those parts of the empire, which were specifically difficult for the monarch to control because of their remoteness and dangerous situation in the European part of the Kingdom.

During this period, in the pages of Latin American newspapers the words nation, citizens, homeland, Hispanics, etc. were beginning to appear very often. Most often, the authors of these publications were members of the Societies of lovers of the country that existed in the main cities of the region and consisted of educated people who believed their primary task was half-enforced inoculation of patriotism to less educated segments of the population. These articles often mentioned the distinctive features of the American nation, and the word homeland until 1810-1820s meant the whole of South America, Mexico, and the Caribbean. 
Although the creation of juntas brought Latin American independence closer, it could not make it immediate. The countries of Latin America had to go through bloody liberation wars, during which a commander and oratorical talent of the man, officially proclaimed the Liberator of South America manifested itself.

The first self-proclaimed independent republic appeared on the territory of present-day Venezuela back in 1811 including with the support of the young aristocrat Simon Bolivar. Unfortunately, it lasted only one year. However, this time was enough in order the future first president of Gran Colombia understood what kind of internal contradictions do not allow Latin Americans to provide decent resistance to the regular army of the Spanish monarch. In its Cartagena Manifesto, published on December 15,1812 , he called the lack of a unifying supranational idea and inability to create a professional army as the first cause. The second factor that hastened the fall of the first republic was ill-distribution of resources which the republican government had. The third one was the consequences of the earthquake, which almost had destroyed Caracas in March 1812. Finally, the fourth force complicating the struggle for independence was the local Catholic church, which laid the ideological foundations of so desired freedom, but then refused to cooperate with the wealthy landowners having picked up the idea. As a result, by 1815 the power of the Spanish monarch in the colonies was restored.

Bolivar and his supporters as pragmatic people learned from their mistakes. The failure of the first republic showed them that their desire was not enough for Latin Americans to become free. Therefore, the already mentioned manifesto said not only of the forces opposing the liberation movement, but also indicated the specific measures and principles of the state structure, which would help to overcome this crisis and release the "Cradle of Independence" - Caracas. So, much more useful tool in the fight against the main political opponent was declared to be the support of the local population, which still had to be enlisted.

Bolivar completely reworked his political strategy. If earlier he was only one of the leaders of the rebels, he now sought to become the most famous of them. For a start, he released all his slaves, promised freedom to slaves of other landowners, ready to join his patriotic army and land to his soldiers that would distinguish themselves in the upcoming battles. In his speeches, he consistently denounced the Spanish government and called Latin Americans to total war.

More detailed description of the representations of Bolivar about the future of Latin America can be found in his Letter from Jamaica, released on September 6, 1815. In this work, he does not stop at the mere enumeration of reasons why liberation wars have not led to the expected results but also states that continuation of the struggle is based not only on a social and political, but also on an ideological basis. He compares the events observed in Latin America, with the final period of the Roman Empire split and says that victory in the fight for independence - is a rebirth of the real Republic, the only fair result, the achievement of which is important for the whole world.

In the same letter, he first expresses the idea that later becomes decisive for many political parties that exist in Latin America in our days. The idea of uniting Latin America in one great and prosperous state-continent expressed by Simon Bolivar, with all its utopian character has proved to be extremely resistant to any fluctuations in policy, has outlived its creator and is widely used in the construction of the nationalist discourse of most modern Latin American countries. Many researchers of Bolivar activity, particularly Vivian Trias, argue that the total number of documents, the author of which is Bolivar presumed to reach ten thousand. Of course, they have not all equally affected transformation of the political system of Latin American countries. However, most of these letters, decrees, proclamations, manifestos, bills and newspaper articles in the English Morning Chronicle, Venezuelan Correo del Orinoco, or Jamaican The Royal Gazzettè and The Jamaica Courant are distinguished by talented style of presentation, in which simplicity and clarity were combined with the persuasiveness, metaphoricalness, and polysemy of language.

Creating its recognizable political discourse, Bolivar resorted to the same means, which with time have not lost the power of its impact and relevance. In his texts mythologizing supplemented by emphasized realism, the symbols clear to every Latin American were connected with classical allegories of Antiquity, and complex philosophical theories took the form available for understanding by the less enlightened people. From work to work, its information message became more specific. Addressing the participants of congresses in Angostura (1819) and Cúcuta (1821), he said a lot about the impossibility of direct application of the European experience on South American soil, the necessity of transformation of any, even the most successful political practices based on local cultural and historical realities, about the benefits of freedom, regained for a part of Latin Americans, but at the same time he insisted on the need to continue the war. 
Realizing their difference from the European civilization, the South America began to seek actively further ways of development. Of course, its constant desire to strengthen regained sovereignty required a corresponding ideological feeding. Through this soon a new leap in the development of local nationalist ideology, caused by two seemingly opposed processes took place, one of which - the formation of independent states we mentioned above. The second most important factor influencing the shape of the modern Latin American nationalism and its particular discourse was a consolidation of states that already had achieved independence that had begun at the time of Bolivar.

To understand how the combination of these processes contributed to the development of Latin American nationalism, let us look at each of them in detail. During the formation of sovereign states, the impossibility of preserving the former borders of each of the newly formed countries within the old Viceroyalties was found out. Having achieved independence from Spain, and, therefore, having passed the period of nationalism, which can be conditionally defined as 'cultural,' Latin Americans, despite their liberator plans, began to develop a more partial differentiation.

It turned out that the population of Latin America is not so homogeneous. That its unity in the struggle for independence could not overcome serious obstacles such as the interests of municipalities turned out into individual countries that almost every major city claims to be the new capital that many recent allies were willing to limit the right of the neighboring Viceroyalty to self-determination, as they had greater military power and intended to increase its territory at its expense, etc.

Having just become separated from Spain and Portugal, the inhabitants of the former colonies immediately launched intercontinental disengagement mechanisms, forgot about the new racial, cultural and historical unity, said about the uniqueness and superiority of each of the old viceroyalties and began to fight with each other.

Finally, boundaries were identified. The South American states indicated their characteristics, formed their public institutions and, having realized the inability to stand alone against stronger opponents naturally moved towards each other.

Intending to give a collective rebuff to the North American expansion, Latin Americans were forced to consolidate and to begin a serious patriotic revision. Not surprisingly, the publications containing essential nationalist markers were among the most common in the newspapers of the time, and the ideas of the future first emperor of the Holy Mexican Catholic Empire Agustin Iturbide were very much in demand. In February 1821 Gaceta de México announced one of Iturbide policy statements in which he immodestly called the population of Mexico "... most believing and religious, heroic and generous nation" of Latin America.

A little later, the Latin American nationalism first became aware of the importance of such traditional elements of European nationalism as religion, race, and cultural identity and became much more aggressive towards those citizens of the new states, the color of whom did not correspond to the representations of the Creole elite on what appearance the true Latin Americans must have.

This led to the so-called perverse decolonization, which made it so that, for example, in Argentina, Uruguay and Chile indigenous population that had survived the invasion of the Conquistadors with losses, was deliberately eliminated in the $\mathrm{XIX}$ century, and not by the Spanish conquerors, but by Creole fighters for freedom, trying to make the local population homogeneous as much as possible, i.e., white. Extermination of Indians and mulattos, sanctioned by the new government, was reinforced by radical publications.

New impetus to the development of Latin American nationalism, which led to its most profound changes, and caused by several factors, belongs to the XX century. Economic crisis broken out in the world at the turn of 20-30s, led to a significant drop in the level of exports and imports, reduction of the domestic market and a sharp decrease in purchasing power.

This resulted in the fact that economic nationalism was added to continental and racial nationalism, that entrenched so firmly that many elements of its discourse are actively and successfully used not only by explicitly nationalistic parties but also by the populist parties of the region up to the present time. Repeated with various periodicity nationalization of North American and British industrial enterprises, called by local leaders as "the return of state assets" for more than a hundred years and being officially sanctioned capture of successful and highly productive plants and factories began in the reign of Juan Peron and still maintains its high ideological positions.

Power and impact that oratory abilities of Peron and especially of his wife Eva had on people were tremendous. The ideas raised by them from the pages of Argentine newspapers, for example, La Prensa and La Capital inspired every Argentine 
that time and with little refinement can drive every Latin American to a frenzy today. They are universally simple and can be expressed in a brief formula: a relentless struggle against imperialism/communism /capitalism, etc. has not been finalized yet, but the victory is near; one needs just to elect the president by his heart. Indeed, as Peron confirmed the regime in power "... cannot be understood, it cannot be described, it can only be felt or not felt. This is the matter of the heart, not the head".

The next impetus for building up the political potential of the Latin American nationalism is considered to be the active involvement of the masses in social movements, participation in which up to $20 \mathrm{~s}$ of the twentieth century was considered to be the exclusive preserve of state elites.

The already mentioned economic crisis combined with autarkic nationalism led to the fact that crowds of the poor rushed to cities from rural areas, which the depleted state treasury was unable to feed.

Consequently, the contradictions in social, cultural and racial relations resulted in the creation of multiple militant parties and organizations of nationalist persuasion, which declared that their primary task was the liquidation of the existing oligarchic system and willingly accepted into their ranks those whom liberals being in power were not taken seriously, because they considered them as declassed uneducated and unable to make political decisions personalities.

Firstly, the official nationalist parties and organizations in Latin America were not much different from each other. They unanimously proclaimed North American and European imperialism, immigrants and descendants of Spanish and Portuguese noble families as the greatest threat to statehood. Gradually, however, every organization started to modify the existing nationalist ideology in agreement with its composition, location, propensity for a socialist (left) or a capitalist (right) nationalism.

Such productive and profitable for winning and retaining of power kind of political discourse as a nationalist discourse, having deep historical roots could not disappear for the sole reason that the word "nationalism" often had come to mean the Third Reich and massacres. Modern Latin American nationalist media discourse is less radical and destructive than the one to the description of which this work is devoted. However, it still does not lose touch with it and proves its effectiveness. The presidents of Venezuela, Bolivia, Ecuador and other countries skillfully used it as candidates and did not abandon it, and during their reign. They have an excellent sense of changes in society and one day they increase, another day they weaken nationalist pathos of their speeches. They constantly appeal to Bolivar, Miranda and Marty, remind of the activity of the "holy Evita," make direct parallels with their fate and achieve that the people give them their votes during elections.

\section{References}

1. Andersson B. Imagined communities. Reflections of the origin and spread of nationalism, p. 55-58.

[1] Ardao A. Estudios latinoamericanos de historia de las ideas. - Caracas, 1978. - p. 111-127.

[2] Bulmer-Thomas V. The economic history of Latin America since independence. - Cambridge, 2003. - P. 48-61.

[3] Castro Leiva Luís, De la Patria boba a la Teología bolivariana. Ensayos de historia intelectual, Caracas, Monte Ávila Editores, 1991. - P. 59-63.

[4] Eisenstadt S. N. The construction of collective identities in Latin America. Beyond the European nation state model // Constructing collective identities and shaping public spheres. - Portland, 1998. - p. 245-261.

[5] Gazeta de Buenos Aires, 6 de deciembre 1810

[6] http://articulo.mercadolibre.com.ar/MLA-437621958-gazeta-de-buenos-ayres-jueves-6-de-setiembre-de-1810JM

[7] González J. E. Tradición y modernidad en la construcción de la nación colombiana // González J. E. Nación y nacionalismo en América Latina. - Bogotá, 2007.

[8] Gutiérrez Escudero A. Juan Pablo Viscardo y su "Carta dirigidaa los españoles americanos" // Revista iberoamericaca de filosofía, política y humanidades. - № 17. - Sevilla, 2007. - P. 323-344.

[9] Miranda y Rodríguez S. F. de Proclamación № 1 a los Pueblos habitantes del Continente Américo-Colombiano http://www.bicentenarios.es/doc/8060802.htm

[10] Morán Bohórquez C. L. Francisco de Miranda. Precursor de las independencias de la América Latina. Caracas, 2006. - p. 159-163.

[11] Paradiso J. Europeísmo y europocentrismo // Puente@Europa. - 2007, p. 57-66. 
[12] Url: http:// www.ba.unibo.it/NR/rdonlyres/DA1908CA-D3F4-46EA-97F1OB4761D343FC/102046/PuenteEuropaN34A5Sumario2_es_en.pdf

[13] Pérez J. Los movimientos precursos de la emancipación en Hispanoamérica. - Madrid. - P. 30-42. - 1977.

[14] Quijano A. Coloniality of power. Eurocentrism and Latin America. - Nepentla: Views From the South 1(3), 2000. - P. 533-580.

[15] Saxe-Fernández J., Delgado G. C. Globalización del terror, amenaza bioterrorista. - La Habana, 2002. - p. 176.

[16] Smith P. Talons of the eagle. Dynamics of US-Latin American Relations. - New York, 1996. - p. 168-200.

[17] Tilli C. The formation of national states in Western Europe. - Princeton University Press, 1975. - P. 17-19.

[18] Trías V. Bolívar. Personajes y episodios. - Montevideo, 1992.

[19] Un continente en movimiento. Migraciones en América Latina // Wehr I. - Madrid, 2006.

[20] Viscardo y Guzmán J.P. Carta a los españoles americanos

[21] http://constitucionweb.blogspot.ru/2010/04/carta-los-espanoles-americanos-juan.html

[22] Zea L. Filosofía de la historia americana. - Mexico, 1978. - P. 220.

[23] Геллнер Э. Нации и национализм. - М., 1991.

[24] Url: http://www.gumer.info/bibliotek_Buks/Polit/gelln/intro.php

[25] Энциклопедия социологии / Сост. А.А. Грицанов, В.Л. Абушенко. - М., 2003.

[26] http://slovari.yandex.ru/dict/sociology/article/soc/soc-

0844.htm?text=\%D0\%BF\%D0\%BE\%D0\%BB\%D0\%B8\%D1\%82\%D0\%B8\%D0\%BA\%D0\%B0\%20\%D0\%BE\% 